\title{
Factors affecting the occurrence of symptomatic intracerebral haemorrhage after intravenous thrombolysis depending on the haemorrhage definition
}

\section{Czynniki wpływajqce na wystqqienie objawowego krwotoku śródmózgowego po dożylnej trombolizie w zależności od definicii krwawienia}

\author{
Monika Śledzińska-Dźwigał, Piotr Sobolewski, Wiktor Szzzuchniak \\ Sandomierski Ośrodek Neurologii z Oddziałem Neurologii i Oddziałem Udarowym, Szpital Specialistyczny Ducha Świętego w Sandomierzu
}

Neurologia i Nerochirurgia Polska 2013; 47, 5: 405-413

DOI: 10.5114/ninp.2013.38220

\begin{abstract}
Background and purpose: Symptomatic intracerebral haemorrhage (sICH) remains the most feared complication of systemic thrombolysis in patients with ischaemic stroke. The aim of the study was to analyze the impact of different factors on the occurrence of $\mathrm{sICH}$, depending on definition used.

Material and methods: We retrospectively evaluated the influence of several factors on the occurrence of sICH (according to definitions used in ECASS2, SITS-MOST and NINDS studies) in 200 patients treated with systemic thrombolysis from 2006 to 2011. Multivariate analysis of impact of individual variables on the occurrence of haemorrhagic transformation (HT) and parenchymal haemorrhage type 2 ( $\mathrm{PH} 2$ ) were performed. Results: Haemorrhagic transformation occurred in 35 cases (17.5\%). SICH was found in 10 cases according to ECASS2, in 7 cases according to SITS and in 13 cases according to NINDS. Older age was related to higher risk of $\mathrm{sICH}$, regardless which definition was used (ECASS2: $p=0.014$, SITS-MOST: $p=0.048$, NINDS: $p=0.008)$, and female sex was related to higher risk of sICH according to NINDS and ECASS2 definition ( $p=0.002$ and $p=0.04$, respectively). Blood glucose level and high NIHSS score ( $>14$ pts) were found as risk factor of $\mathrm{sICH}$ in ECASS2 definition $(p=0.044$ and $p=0.03$, respectively). In multivariate logistic regression higher NIHSS scores were associated with HT independent of age, gender and glucose level $(p=0.012)$. Multivariate analysis showed no impact of age, gender, severity of stroke and glucose level on presence of $\mathrm{PH} 2$.
\end{abstract}

\section{Streszczenie}

Wstęp i cel pracy: Objawowy krwotok wewnątrzmózgowy (symptomatic intracerebral haemorrhage - sICH) pozostaje najgroźniejszym powikłaniem systemowej trombolizy u chorych na ostry udar niedokrwienny mózgu. Celem pracy była ocena wpływu różnych czynników na występowanie sICH w zależności od zastosowanej definicji krwotoku.

Materiał i metody: Przeanalizowano retrospektywnie wpływ czynników epidemiologicznych i klinicznych na występowanie sICH (zgodnie $\mathrm{z}$ definicjami: ECASS2, SITS-MOST i NINDS) u chorych leczonych trombolitycznie od $2006 \mathrm{r}$. do 2011 r. Przeprowadzono analizę wieloczynnikową wpływu poszczególnych czynników na występowanie transformacji krwotocznej (HT) oraz krwiaków śródmiąższowych typu 2 (PH2).

Wyniki: Transformacja krwotoczna wystąiła w 35 przypadkach (17,5\%), SICH stwierdzono w 10 przypadkach zgodnie z definicją ECASS2, w 7 wg SITS-MOST i 13 wg NINDS. Starszy wiek wiązał się z większym ryzykiem sICH niezależnie od zastosowanej definicji (ECASS2: $p=0,014$, SITS-MOST: $p=0,048$, NINDS: $p=0,008)$, a płeć żeńska zwiększała ryzyko sICH zgodnie z definicją NINDS $i$ ECASS2 (odpowiednio $p=0,002$ i $p=0,04$ ). Stężenie glukozy we krwi i wysoka punktacja w skali NIHSS (> 14 pkt) były czynnikami ryzyka zgodnie $z$ definicją ECASS2 (odpowiednio $p=0,044 \mathrm{i} p=0,03$ ). W wieloczynnikowej regresji logistycznej wysoka punktacja w skali NIHSS wiązała się $\mathrm{z}$ występowaniem $\operatorname{HT}(p=0,012)$. W analizie wieloczynni-

Correspondence address: dr Monika Śledzińska-Dźwigat, SPZZOZ Sandomierz, Schinzla 13, 27-600 Sandomierz, Poland, e-mail: msledzinska@onet.eu Received: 22.02.2012; accepted: 5.02.2013 
Conclusions: Definition of sICH can determine variables that are related to a high risk of this complication. In our study most factors correlated with sICH using the ECASS2 definition.

Key words: stroke, thrombolytic therapy, definition of symptomatic intracranial haemorrhage. kowej nie stwierdzono wpływu wieku, płci, nasilenia udaru w punktacji NIHSS ani stężenia glukozy na wystąpienie PH2.

Wnioski: Definicja sICH może określić zmienne, które są związane $\mathrm{z}$ dużym ryzykiem tego powikłania. W badanej grupie chorych najwięcej czynników wiązało się z sICH definiowanym zgodnie z ECASS2.

Słowa kluczowe: udar, leczenie trombolityczne, definicje objawowego krwawienia wewnątrzczaszkowego.

Therefore we aimed to evaluate the relationship between several factors and the presence of $\mathrm{sICH}$ according to different definitions, by what we tried to determine which definition is most sensitive in this respect.

\section{Material and methods}

We retrospectively evaluated the influence of epidemiological and clinical factors on the occurrence of sICH, according to ECASS2, SITS-MOST and NINDS definitions in 200 consecutive Caucasian patients treated with intravenous thrombolysis between September 2006 and March 2011, in stroke unit in Sandomierz. Our study center was recognized as a stroke unit according to the Polish national criteria and was equipped with the proper monitoring and diagnostic facilities [11]. All patients were examined at the time of admission by a stroke physician, and the severity of stroke symptoms was assessed using the NIHSS [12]. Cerebral thrombolysis with the intravenous infusion of rt-PA was administered according to the current guidelines [13]. Because the Polish guidelines changed in June 2010, patients treated within the 4.5-hour time window and patients over 80 years of age were included in the study [14]. All patients had CT of the brain performed prior to treatment, 22-36 hours after the start of treatment and on the seventh day, as well as in case of deterioration of the neurological status. All our patients received standard care, typical of a stroke unit, including rehabilitation, psychological and speech therapy as well. We used the ECASS2 classification based on CT image and radiological features of haemorrhagic transformation $[8,15]$.

The study protocol was accepted by the Ethics Committee of Regional Chamber of Physicians in Kielce (Consent No. 8/2011). All personal data of the analyzed patients were treated confidentially. 


\section{Statistical methods}

Statistical analysis was performed with Statistica 6.0. Univariate analyses were performed and $\chi^{2}$ tests with appropriate corrections (Yates correction, Fisher exact test) for sample size and expected counts and nonparametric Mann-Whitney $U$-tests were used because of skewed distribution. The multivariate analysis was performed with the use of multiple logistic regression. Calculations were not always mathematically possible due to the limited number of observations, therefore the multivariate analysis was performed for haemor- rhagic transformation and parenchymal haematoma type 2. The results of the logistic regression models were presented as odds ratios (ORs) and the corresponding $95 \%$ confidence intervals (CIs). The level of significance was set at $p<0.05$.

\section{Results}

General characteristics of the group of patients are shown in Table 1. Patients with heart disease, especially with atrial fibrillation, were abundant in our study population.

Table 1. Characteristics of group of patients

\begin{tabular}{|c|c|}
\hline Variable & \\
\hline \multicolumn{2}{|l|}{ Gender } \\
\hline Female & $88(44 \%)$ \\
\hline Male & $112(56 \%)$ \\
\hline Age (years) $[$ mean $\pm \mathrm{SD},($ range $)]$ & $69.07 \pm 10.57(41-92)$ \\
\hline Arterial hypertension & $134(67 \%)$ \\
\hline Diabetes mellitus & $25(12.5 \%)$ \\
\hline Dyslipidemia & $154(77.0 \%)$ \\
\hline Atrial fibrillation & $68(34.0 \%)$ \\
\hline Previous stroke & $33(16.5 \%)$ \\
\hline Coronary disease & $105(52.5 \%)$ \\
\hline Previous smoker & $36(18 \%)$ \\
\hline Current smoker & $40(20.0 \%)$ \\
\hline Dose of rt-PA (mg) [mean $\pm \mathrm{SD}$, (range) $]$ & $64.2 \pm 12.8(50-80)$ \\
\hline Onset-to-needle time (min.) $[$ mean $\pm \mathrm{SD}$, (range)] & $150.5 \pm 41.2(45-290)$ \\
\hline Door-to-needle time (min.) $[$ mean $\pm \mathrm{SD}$, (range) $]$ & $63.7 \pm 28.8(10-190)$ \\
\hline \multicolumn{2}{|l|}{ Clinical stroke syndrome (OSCP) } \\
\hline Total anterior circulation infarct & $54(27.0 \%)$ \\
\hline Partial anterior circulation infarct & $102(51.0 \%)$ \\
\hline Lacunar infarct & $43(21.5 \%)$ \\
\hline Posterior circulation infarct & $1(0.5 \%)$ \\
\hline Baseline NIHSS score, mean \pm SD & $12.3 \pm 5.0$ \\
\hline \multicolumn{2}{|l|}{ Patients with the following NIHSS scores: } \\
\hline $0-7$ & $43(21.5 \%)$ \\
\hline $8-14$ & $90(45.0 \%)$ \\
\hline$\geq 15$ & $67(33.5 \%)$ \\
\hline
\end{tabular}

Data are shown as number (\%) if not otherwise stated

OCSP - Oxford Community Stroke Project, NIHSS - National Institutes of Health Stroke Scale 
Table 2. Haemorrhagic transformation in analyzed group of patients

\begin{tabular}{|lc|}
\hline Type of intracerebral haemorrhage & N (\%) \\
\hline Any intracerebral haemorrhage & $35(17.5)$ \\
\hline Haemorrhagic infarct type 1 & $7(3.6)$ \\
\hline Haemorrhagic infarct type 2 & $8(4.0)$ \\
\hline Parenchymal haematoma type 1 & $8(4.0)$ \\
\hline Parenchymal haematoma type 2 & $8(4.0)$ \\
\hline $\begin{array}{l}\text { Symptomatic intracerebral haemorrhage } \\
\text { - ECASS }\end{array}$ & $10(5.0)$ \\
\hline $\begin{array}{l}\text { Symptomatic intracerebral haemorrhage } \\
- \text { SITS-MOST }\end{array}$ & $7(3.5)$ \\
\hline $\begin{array}{l}\text { Symptomatic intracerebral haemorrhage } \\
\text { - NINDS }\end{array}$ & $13(6.5)$ \\
\hline Parenchymal haematoma remote type 1 & $4(2.0)$ \\
\hline Parenchymal haematoma remote type 2 & 0 \\
\hline
\end{tabular}

ECASS - European Cooperative Acute Stroke Study, SITS-MOST - Safe Implementation of Thrombolysis in Stroke - Monitoring Study, NINDS - National Institute of Neurological Disorders and Stroke

Haemorrhagic transformation occurred in $17.5 \%$ of cases. Symptomatic ICH was found in $5 \%$ of cases (according to ECASS2), 3.5\% (SITS-MOST) or in 6.5\% (NINDS), depending on definition (Table 2).

Older age was related to higher risk of sICH, regardless which definition was used (ECASS2, $p=0.014$; SITS-MOST, $p=0.048$; NINDS, $p=0.008)$. Female sex was related to higher risk of sICH according to NINDS and ECASS2 definition $(p=0.002$ and $p=0.04$, respectively). Blood glucose level and high NIHSS score ( $>14$ pts) were risk factors of sICH in ECASS2 definition $(p=0.044$ and $p=0.03$, respectively) (Table 3).

In multivariate logistic regression, higher NIHSS scores were associated with haemorrhagic transformation independent of age, gender and glucose level $(p=0.012)$. Multivariate analysis showed no impact of age, gender, severity of stroke according to NIHSS score and glucose level on presence of parenchymal haematoma type 2 (Table 4 ).

\section{Discussion}

Haemorrhagic transformation is the most serious complication of thrombolytic therapy. In fact, it is a group of haemorrhagic changes in the brain, with different pathogenesis and clinical significance [16]. Some of haemorrhagic transformations seem to be natural course of the ischaemic injury, which probably would appear even without thrombolytic treatment $[17,18]$. Only a fraction of haemorrhagic transformations is related to deterioration of the patient's status and are defined as sICH. Analysis of these cases is difficult because of the multiplicity of definitions of $\mathrm{sICH}$. The influence of different factors on the occurrence of sICH differed depending on the use of one out of three definitions.

Mazya et al. [19] analyzed data from 31627 patients treated with intravenous alteplase enrolled in the SITS International Stroke Thrombolysis Register. The outcome measure was sICH per the SITS-MOST definition. The authors identified 9 independent risk factors for sICH: baseline NIHSS score, serum glucose, systolic blood pressure, age, body weight, stroke onset to treatment time, aspirin or combined aspirin and clopidogrel, and history of hypertension.

In our study, older age was related to sICH regardless which definition was used. Older age was defined as independent risk factor for $\mathrm{sICH}$ in several previous studies $[7,8,10,20]$ but another studies did not confirm this association $[21,22]$. In most studies of thrombolytic therapy, patients under 80 were included and only in some of trials treatment of elderly patients with rt-PA was allowed. Recently published results of the Third International Stroke Trial IST-3 show survival benefits of rt-PA in elderly stroke patients [23].

Gender differences in coagulation and fibrinolytic factors have been reported in acute ischaemic stroke [24]. Meseguer et al. collected efficacy and safety outcomes for patients treated with rt-PA in their center and they also performed a systemic PubMed literature search for previous 16 studies that evaluated the gender effect among intravenous rt-PA-treated patients. None of these studies supported a gender difference in favourable outcome, and one suggested an increased risk of mortality in men. In unadjusted partial metaanalysis in all patients from these studies, the authors found a trend toward a lower risk of sICH in women [25]. In our population, female sex was correlated with higher risk of sICH according to NINDS and ECASS2 definitions.

High blood glucose level is a well-recognized risk factor of sICH $[9,10,26,27]$. In patients with acute ischaemic stroke from both parts of NINDS trial, higher admission glucose levels were associated with significantly lower odds for desirable clinical outcomes and significantly higher odds for $\mathrm{sICH}$, regardless of rt-PA treatment [28]. High blood glucose was significantly higher in the group of patients with sICH in the 


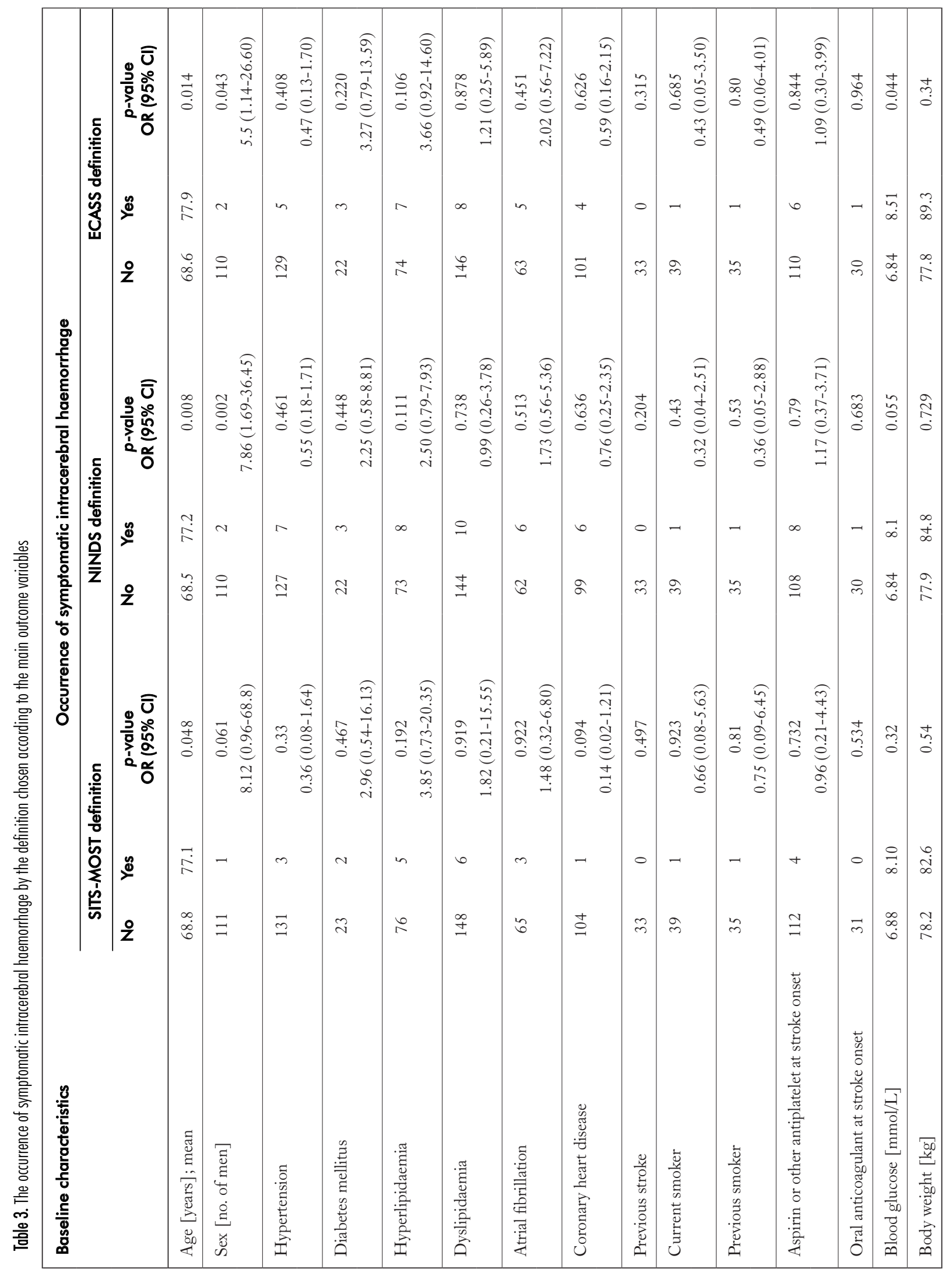




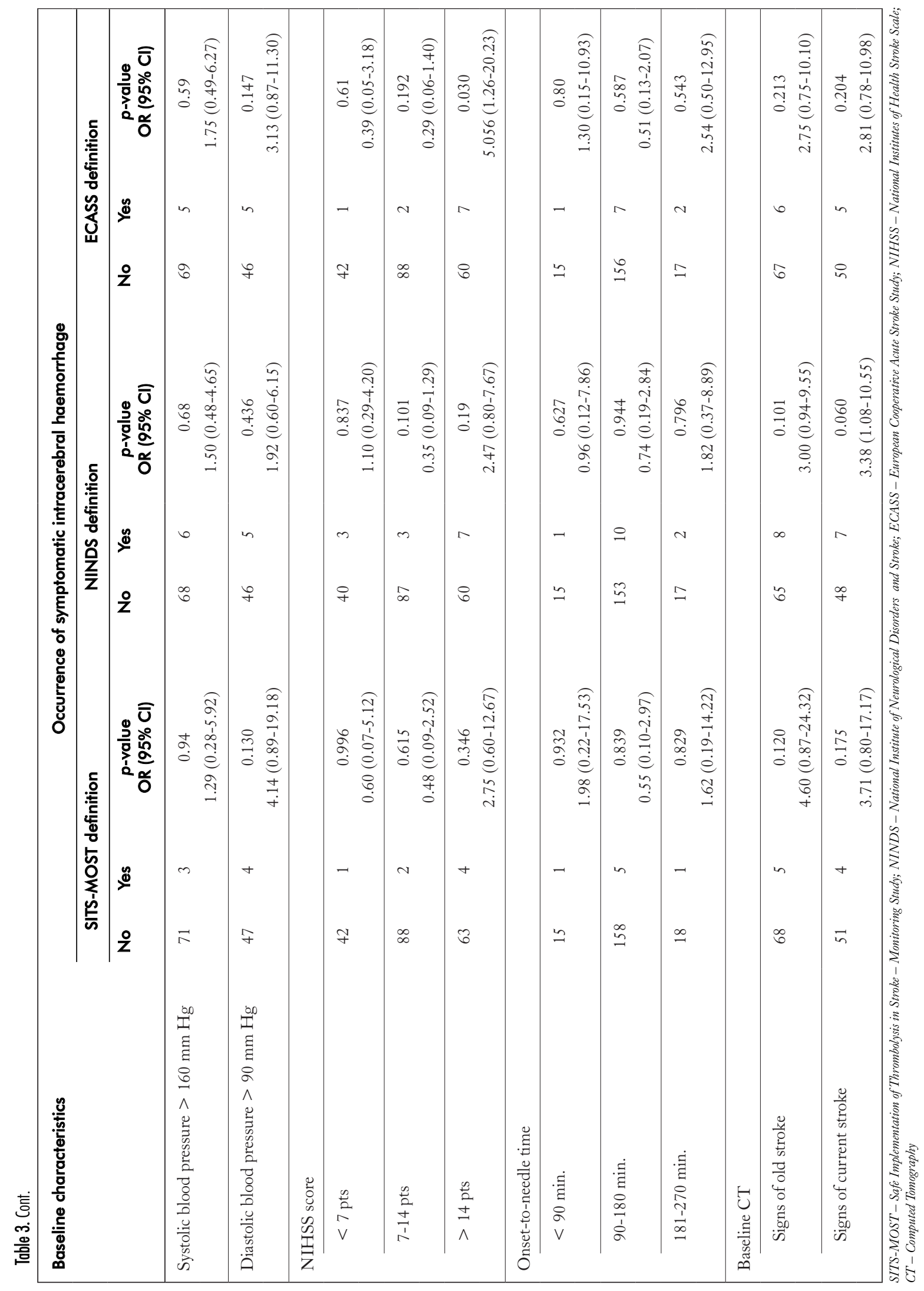


Table 4. Multivariate logistic regression analysis showing factors associated with a haemorrhagic transformation and parenchymal haematoma

\begin{tabular}{|c|c|c|c|c|}
\hline \multirow[t]{2}{*}{ Variables } & \multicolumn{2}{|c|}{$\begin{array}{l}\text { Haemorrhagic } \\
\text { transformation }\end{array}$} & \multicolumn{2}{|c|}{$\begin{array}{c}\text { Parenchymal } \\
\text { haematoma type } 2\end{array}$} \\
\hline & OR & $95 \% \mathrm{Cl}$ & OR & $95 \% \mathrm{Cl}$ \\
\hline Age (each year) & 0.968 & $0.932-1.007$ & 0.967 & $0.896-1.043$ \\
\hline Male gender & 0.815 & $0.370-1.796$ & 0.547 & $0.108-2.773$ \\
\hline Stroke severity according to NIHSS score (each point) & 1.101 & $1.020-1.187$ & 0.893 & $0.775-1.030$ \\
\hline Glucose level (stepwise increase of $1 \mathrm{mmol} / \mathrm{L}$ ) & 0.909 & $0.778-1.062$ & 0.908 & $0.684-1.205$ \\
\hline
\end{tabular}

ECASS2 trial [8]. In our study, high level of glucose was associated with sICH according to the ECASS2 protocol definition only.

Higher NIHSS score was estimated as an independent risk factor of sICH in several previous studies [7,9,29-32]. We also found this association in our patients but only according to ECASS2 definition.

There are no consistent data that chronic use of aspirin or other antiplatelet agents prior to treatment with rt-PA increases risk of sICH. Several studies have indicated that prior antiplatelet therapy increases the risk of ICH $[10,27,29,33]$. Only one study shows that prior anticoagulant therapy is an independent predictor of ICH [34]. We did not find influence of chronic use of antiplatelet or anticoagulant drugs prior to thrombolytic therapy on occurrence of sICH.

The presence of early ischaemic changes in baseline $\mathrm{CT}$ was indicated as significant predictor of $\mathrm{sICH}$ after thrombolysis in several previous studies $[6,20]$. We did not find such relationship in our patients. We did not find any association between sICH and old ischaemic changes in baseline $\mathrm{CT}$ either.

Direct comparison of sICH rates in different studies evaluating safety of systemic cerebral thrombolysis is complicated by the variability of definitions of sICH. A few studies comparing the definitions of sICH were published. In most of them, clinical usefulness of these definitions was analysed, on the base of evaluation of long-term outcome and mortality within 90 days [35, 36]. Gumbinger et al. [37] compared four definitions of sICH: NINDS, ECASS2, SITS and ECASS3 in terms of mortality, poor and good outcome after 90 days in group of 314 patients treated with intravenous rt-PA. None of these definitions featured an optimal combination of prediction of mortality and outcome.

The analysis of 6483 patients treated with alteplase from SITS-MOST registry showed that systolic blood pressure, atrial fibrillation, and body weight were pre- dictors of sICH and current smokers had a lower rate of sICH [10]. The analysis of Polish stroke patients treated with intravenous thrombolysis entered into the SITS registry showed that certain group of patients was treated not fully adhering to the European license in Poland. Those patients, however, were not at increased risk of sICH or death [38]. To determine the role of various factors on the occurrence of $\mathrm{sICH}$, the data from the Helsinki Stroke Thrombolysis Registry suggest that the most suitable definition of postthrombolytic sICH would be the ECASS2. Impact of the ECASS2-defined sICH differed only slightly from the NINDS. The occurrence of sICH according to these definitions was independently associated (or showed a trend) with similar parameters: age, baseline NIHSS score, baseline glucose level, presence of hyperdense artery sign and early infarct signs on admission imaging, and statin use. The frequencies of SITS-defined sICH in various thrombolysis cohorts were lower compared with other definitions [36]. Also in our study, most factors were related to sICH using the ECASS2 definition.

\section{Conclusions}

Definition of sICH can determine variables that are related to a high risk of this complication. In our study, the highest number of factors i.e. older age, female sex, blood glucose level and high NIHSS score ( $>14$ pts) was associated with $\mathrm{sICH}$ using the ECASS2 definition.

\section{Disclosure}

Authors report no conflict of interest.

\section{References}

1. Lloyd-Jones D., Adams R.J., Brown T.M., et al. Executive summary: heart disease and stroke statistics-2010 update: a report 
from the American Heart Association. Circulation 2010; 121: 948-954.

2. Członkowska A., Ryglewicz D. Epidemiology of cerebral stroke in Poland. Neurol Neurochir Pol 1999; 32 (Suppl 6): 99-103.

3. Członkowska A., Ryglewicz D., Weissbein T., et al. A prospective community-based study of stroke in Warsaw, Poland. Stroke 1994; 25: 547-555.

4. Ryglewicz D., Milewska D. Epidemiologia udaru mózgu. In: Mazur R., Książkiewicz B., Nyka W.M. [eds.]. Udar mózgu w praktyce lekarskiej. $2^{\text {nd }}$ edition. Via Medica, Gdańsk 2010, pp. 5-14.

5. Hacke W., Kaste M., Bluhmki E., et al., for the ECASS Investigators. Thrombolysis with alteplase 3 to 4,5 hours after acute ischaemic stroke. N Engl J Med 2008; 359: 1317-1329.

6. The National Institute of Neurological Disorders and Stroke rt-PA StrokeStudy Group. Tissue plasminogen activator for acute ischemic stroke. $N$ Engl J Med 1995; 333: 1581-1587.

7. Fiorelli M., Bastianello S., von Kummer R., et al. Hemorrhagic transformation within 36 hours of a cerebral infarct: relationships with early clinical deterioration and 3-month outcome in the European Cooperative Acute Stroke Study I (ECASS I) cohort. Stroke 1999; 30: 2280-2284.

8. Hacke W., Kaste M., Fieschi C., et al. Randomised doubleblind placebo-controlled trial of thrombolytic therapy with intravenous alteplase in acute ischaemic stroke (ECASS II). Lancet 1998; 352: 1245-1251.

9. Wardlaw J.M., Zoppo G., Yamaguchi T., et al. Thrombolysis for acute ischaemic stroke. Cochrane Database Syst Rev 2003; 3: CD000213.

10. Wahlgren N., Ahmed N., Errikson N., et al., for the SITSMOST Investigators. Multivariable analysis of outcome predictors and adjustment of main outcome results to baseline data profile in randomized controlled trials: Safe Implementation of Thrombolysis in Stroke-Monitoring Study (SITS-MOST). Stroke 2008; 39: 3316-3322.

11. Członkowska A., Sarzynska-Długosz I., Niewada M., et al. Eligibility of stroke units in Poland for administration of intravenous thrombolysis. Eur J Neurol 2006; 13: 220-224.

12. Lyden P., Brott T., Tilley B., et al. Improved reliability of the NIH Stroke Scale using video training. NINDS TPA Stroke Study Group. Stroke 1994; 25: 2220-2226.

13. Adams H.P., del Zoppo G., Alberts M.J., et al. Guidelines for the early management of adults with ischemic stroke. A Guideline From the American Heart Association/American Stroke Association Stroke Council, Clinical Cardiology Council, Cardiovascular Radiology and Intervention Council, and the Atherosclerotic Peripheral Vascular Disease and Quality of Care Outcomes in Research Interdisciplinary Working Groups: The American Academy of Neurology affirms the value of this guideline as an educational tool for neurologists. Circulation 2007; 115: e478-e534.

14. Postępowanie w udarze mózgu. Wytyczne Grupy Ekspertów Sekcji Chorób Naczyniowych Polskiego Towarzystwa Neurologicznego. Neurol Neurochir Pol 2012; 46 (Suppl 1): 24-29.

15. Larrue V., von Kummer R., Müller A., et al. Risk factors for severe hemorrhagic transformation in ischemic stroke patients treated with recombinant tissue plasminogen activator a sec- ondary analysis of the European-Australasian Acute Stroke Study (ECASS II). Stroke 2001; 32: 438-441.

16. Trouillas P., von Kummer R. Classification and pathogenesis of cerebral hemorrhage after thrombolysis in ischemic stroke. Stroke 2006; 37: 556-561.

17. Motto C., Ciccone A., Aritzu E., et al. MAST-I Collaborative Group. Hemorrhage after an acute ischemic stroke. Stroke 1999; 30: 761-764.

18. Toni D., Fiorelli M., Bastianello S., et al. Hemorrhagic transformation of brain infarct: predictability in the first 5 hours from stroke onset and influence on clinical outcome. Neurology 1996; 46: 341-345.

19. Mazya M., Egido J.A., Ford G.A., et al. for the SITS investigators. Predicting the risk of symptomatic intracerebral hemorrhage in ischemic stroke treated with intravenous alteplase: safe Implementation of Treatments in Stroke (SITS) symptomatic intracerebral hemorrhage risk score. Stroke 2012; 43: 1524-1531.

20. Bluhmki E., Chamorro A., Dávalos A., et al. Stroke treatment with alteplase given 3.0-4.5 h after onset of acute ischaemic stroke (ECASS III): additional outcomes an subgroup analysis of a randomised controlled trial. Lancet Neurol 2009; 12: 1095-1102.

21. Berrouschot J., Röther J., Glahn J., et al. Outcome and severe hemorrhagic complications of intravenous thrombolysis with tissue plasminogen activator in very old ( $>80$ years) stroke patients. Stroke 2005; 36: 2421-2425.

22. Engelter S.T., Reichhart M., Sekoranja L., et al. Thrombolysis in stroke patients aged 80 years and older: Swiss survey of IV thrombolysis. Neurology 2005; 65: 1795-1798.

23. IST-3 collaborative group. The benefits and harms of intravenous thrombolysis with recombinant tissue plasminogen activator within $6 \mathrm{~h}$ of acute ischaemic stroke (the Third International Stroke Trial [IST-3]): a randomised controlled trial. Lancet 2012; 379: 2352-2363.

24. Kain K., Carter A.M., Bamford J.M., et al. Gender differences in coagulation and fibrinolysis in white subjects with acute ischemic stroke. J Thromb Haemost 2003; 1: 390-392.

25. Meseguer E., Mazighi M., Labreuche J., et al. Outcomes of intravenous recombinant tissue plasminogen activator therapy according to gender. A clinical registry study and systematic review. Stroke 2009; 40: 2104-2110.

26. Hill M.D., Buchan A.M., for the Canadian Alteplase for Stroke Effectiveness Study (CASES) Investigators. Thrombolysis for acute ischemic stroke: results of the Canadian Alteplase for Stroke Effectiveness Study. CMAJ 2005; 172: 1307-1312.

27. Tanne D., Kasner S.E., Demchuk A.M., et al. Markers of increased risk of intracerebral hemorrhage after intravenous recombinant tissue plasminogen activator therapy for acute ischemic stroke in clinical practice: the Multicenter rt-PA Stroke Survey. Circulation 2002; 105: 1679-1685.

28. Bruno A., Levine S.R., Frankel M.R., et al. Admission glucose level and clinical outcomes in the NINDS rt-PA Stroke Trial. Neurology 2002; 59: 669-674.

29. Cucchiara B., Kasner S.E., Tanne D., et al. for the SAINT Investigators. Factors associated with intracerebral hemorrhage after thrombolytic therapy for ischemic stroke pooled analysis of placebo data from the Stroke-Acute Ischemic NXY Treatment (SAINT) I and SAINT II Trials. Stroke 2009; 40: 3067-3072. 
30. Thomalla G., Schwark C., Sobesky J., et al. for the MRI in Acute Stroke Study Group of the German Competence Network Stroke. Outcome and symptomatic bleeding complications of intravenous thrombolysis within 6 hours in MRI-selected stroke patients comparison of a German multicenter study with the pooled data of ATLANTIS, ECASS, and NINDS tPA Trials. Stroke 2006; 37: 852-858.

31. Hacke W., Donnan G., Fieschi C., et al. ATLANTIS Trials Investigators; ECASS Trials Investigators; NINDS rt-PA Study Group Investigators. Association of outcome with early stroke treatment: pooled analysis of ATLANTIS, ECASS, and NINDS rt-PA stroke trials. Lancet 2004; 363: 768-774.

32. Kablau M., Kreisel S.H., Sauer T., et al. Predictors and early outcome of hemorrhagic transformation after acute ischemic stroke. Cerebrovasc Dis 2011; 32: 334-341.

33. Uyttenboogaart M., Koch M.W., Koopman K., et al. Safety od antiplatelet therapy prior intravenous thrombolysis in acute ischemic stroke. Arch Neurol 2008; 65: 607-611.

34. Prabhakaran S., Rivolta J., Vieira J.R., et al. Symptomatic intracerebral hemorrhage among eligible warfarin-treated patients receiving intravenous tissue plasminogen activator for acute ischemic stroke. Arch Neurol 2010; 67: 559-563.

35. Southerland A.M., Malik S., Johnstone K.C. Symptomatic ICH and outcomes in patients after IV tPA. A business of risk or risky business? Neurology 2011; 77: 315-316.

36. Strbian D., Sairanen T., Meretoja A., et al. Patient outcomes from symptomatic intracerebral hemorrhage after stroke thrombolysis. Neurology 2011; 77: 341-348.

37. Gumbinger C., Gruschka P., Böttinger M., et al. Improved prediction of poor outcome after thrombolysis using conservative definitions of symptomatic hemorrhage. Stroke 2012; 43: 240-242.

38. Karliński M., Kobayashi A., Litwin T., et al. Intravenous thrombolysis for acute ischaemic stroke in patients not fully adhering to the European licence in Poland. Neurol Neurochir Pol 2012; 46: 3-14. 